\title{
Notes
}

\section{Reforming the One Step at a Time Justification in Equal Protection Cases}

The Supreme Court recently decided that under the equal protection clause of the Fourteenth Amendment, ${ }^{1}$ Minnesota may address environmental and energy problems by banning plastic nonrefillable milk containers, even if the state does not prohibit the use of potentially harmful paper nonrefillable containers. ${ }^{2}$ The Court reasoned that the legislature could proceed one step at a time toward its goals, addressing the problem of plastic containers first and leaving paper containers for later consideration. ${ }^{3}$ Although this justification for upholding a legislative classification was first articulated by the Court over twenty-five years ago, ${ }^{4}$ its meaning still remains unclear. This Note provides an analytical framework for the one step at a time justification. It argues that courts can properly rely on the one step at a time rationale to uphold certain types of otherwise indefensible unequal treatment, if courts simultaneously encourage the legislature to take further steps.

Part I of the Note examines the present role of the one step at a time justification in equal protection analysis. It describes the broad range of major cases in which the justification has been used and highlights the inconsistencies within and among those decisions. Part II argues that the one step at a time principle should be a doctrine of timebound legislative purposes that would add a final step to a court's means-end inquiry. Part III argues that the character of judicial decisionmaking hinders relitiga-

1. U.S. CONST, amend. XIV, $§ 1$ ("No State shall ... deny to any person within its jurisdiction the equal protection of the laws.")

2. Minnesota v. Clover Leaf Creamery Co., 101 S. Ct. 715 (1981).

3. Id. at 725 ("[A] legislature 'may implement [its] program step by step, . . adopting regulations that only partially ameliorate a perceived evil and deferring complete elimination of the evil to future regulations." ") (quoting New Orleans v. Dukes, 427 U.S. 297, 303 (1976)). Reversing the Minnesota Supreme Court, 289 N.W.2d 79 (1979), the Court also held that the legislature's ban on plastic milk jugs was rationally related to the goal of easing the solid-waste problem, and that the state court erred in substituting its judgment for that of the legislature on the issue of whether plastic containers were more harmful than paper containers. Id. at 725-27.

4. See Williamson v. Lee Optical Co., 348 U.S. 483, 489 (1955). Lee Optical is the earliest case generally cited for the one step at a time justification, though similar language appears in earlier opinions. See, e.g., New York v. United States, 331 U.S. 284, 343 (1947) (Interstate Commerce Commission may attack problems "one step at a time"); Semler v. Dental Examiners, 294 U.S. 608, 610 (1935) ("The State was not bound . . . to strike at all evils at the same time. . . .") 
tion or legislative reconsideration of one step at a time cases. It suggests that when a court holds that statutory classifications are constitutional solely on the basis of a one step at a time analysis, its holding should be limited to a specified number of years.

\section{The One Step at a Time Justification-An Avenue for Judicial Deference}

The equal protection clause requires courts to examine the relationship between statutory classifications and the legislative goals the statute serves when judging the validity of a statute. ${ }^{5}$ This inquiry includes an identification of legitimate legislative purposes, ${ }^{6}$ an evaluation of the extent to which the challenged classification furthers those purposes, ${ }^{7}$ and a balancing of the competing interests asserted. ${ }^{8}$ When a fundamental right is not

5. See, e.g., Rinaldi v. Yeager, 384 U.S. 305, 308-09 (1966) (classifications must have some relevance to purpose of statute); McLaughlin v. Florida, 379 U.S. 184, 191 (1964) (statutory classifications must be reasonable in light of statute's purpose); Tussman \& tenBrock, The Equal Protection of the Laws, 37 CALIF. L. REV. 341, 346 (1949) (reasonable classification includes all persons similarly situated with respect to purposes of law).

Some commentators assert that equal protection analysis should not concern itself with the actual operation of laws but with the process by which those laws are formulated. See, e.g., J. ELY, DEMOCRACY AND DISTRUST 87 (1980) (Constitution concerned with procedural fairness and broad participation in processes and distributions of government). Other commentators have pointed out, however, that a process-oriented view of the equal protection clause is inadequate or meaningless to the extent that it attempts to be independent of substantive value choices. See Tribe, The Puzzling Persistence of Process-Based Constitutional Theories, 89 YALE L. J. 1063, 1064 (1980) (process theory is "radically indeterminate and fundamentally incomplete"). Without entering the debate between the process-oriented and outcome-oriented approaches, one can conclude that means-end rationality is one of the values that courts consistently have declared to be embodied in the equal protection clause.

6. See, e.g., Orr v. Orr, 440 U.S. 268, 279-80 (1979) (reinforcing wife's dependent role in family is impermissible objective); United States Dep't of Agriculture v. Moreno, 413 U.S. 528, 534 (1973) ("bare congressional desire to harm a politically unpopular group" is impermissible purpose); Note, Equal Protection: A Closer Look At Closer Scrutiny, 76 MICH. L. REV. 771, 799 (1978) ("The requirement of a legitimate purpose is probably the single most important protection of misfit review.")

7. The evaluation of the means-end relationship must be informed by substantive constraints; in purely formal terms, legislative means will always be rationally, and in fact tautologically, related to some set of ends. See United States R.R. Retirement Bd. v. Fritz, 101 S. Ct. 453, 462 (1980) (Stevens, J., concurring) ("II]f any 'conceivable basis' for a discriminatory classification will repel a constitutional attack on the statute, judicial review will constitute a mere tautological recognition of the fact that Congress did what it intended to do."); Sandalow, Racial Preferences in Higher Education: Political Responsibility and the Judicial Role, 42 U. CHI. L. REV. 653, 654-63 (1975) (any means-end rationality requirement can be satisfied tautologically); Note, Legislative Purpose, Rationality, and Equal Protection, 82 YALE L.J. 123, 128 (1972) (same).

8. Present doctrine formally recognizes two levels of scrutiny. "Strict scutiny" is appropriate when the right asserted is fundamental, such as the right to vote or to travel, or when the classification is suspect, such as a classification based on race. Developments in the Law - Equal Protection, 82 HARV. L. REV. 1065, 1103 (1969). Under strict scrutiny the classification must be necessary to promote a compelling state interest. See, e.g., In re Griffiths, 413 U.S. 717, 721-22 (1973) (alienage); Shapiro v. Thompson, 394 U.S. 618, 634 (1969) (right to travel). Classifications not subject to strict scrutiny need only be "rationally related" to a constitutionally permissible purpose. See, e.g., Maher v. Roe, 432 U.S. 464, 478 (1977) (abortion funding); San Antonio School Dist. v. Rodriguez, 411 U.S. 1, 17 (1973) (school financing). In recent years, an intermediate level of review has emerged in cases involving gender-based classifications. It requires that the classification be "substantially related" 
implicated and the classification is not suspect, the Court has tolerated classifications that are underinclusive. ${ }^{9}$ The one step at a time rationale is one of the justifications advanced by the Court for such legislative underinclusiveness. ${ }^{10}$ Yet the Court has never fully explained the meaning of the justification.

On its face, the phrase "one step at a time" implies a series of measures enacted over a period of time to deal with different facets of the same problem, ultimately producing a regulatory scheme consistent with the notion of equal treatment. Each step is a necessary part of the whole regulatory plan, but is not sufficient in and of itself. It is unclear, however, whether a legislature may take only the first step. In Williamson v. Lee Optical, ${ }^{11}$ for example, the Court upheld an Oklahoma law restricting advertising by opticians but not by sellers of ready-to-wear glasses, stating that legislative reform "may take one step at a time . . ."12 By invoking the one step at a time justification, the Court in Lee Optical appeared to sanction the legislature's intentions, but only to the extent that those intentions continued to be implemented. The Court went on, however, to imply that it was not concerned with any temporal scheme, holding that "[t]he legislature may select one phase of one field and apply a remedy there, neglecting the others. ..."13 Thus, it is unclear whether the Court

to an "important" state interest. See, e.g., Califano v. Webster, 430 U.S. 313, 317 (1977) (old age benefits); Craig v. Boren, 429 U.S. 190, 197 (1976) (alcoholic beverage regulation).

9. L. TRIBE, AMERICAN CONSTITUTIONAL LAW 997 (1978); see, e.g., Massachusetts Bd. of Retirement v. Murgia, 427 U.S. 307, 316 (1976) ("[W] the Equal Protection Clause merely because the classifications made by its laws are imperfect.' "); Metropolis Theatre Co. v. Chicago, 228 U.S. 61, 69-70 (1913) (practical problems of government may justify "rough accommodations").

In the last forty years, the Court has held only one economic regulatory statute unconstitutional under the rationality standard, see Morey v. Doud, 354 U.S. 457 (1957) (striking down statute exempting money orders from currency exchange regulation), and that decision was subsequently overturned. See New Orleans v. Dukes, 427 U.S. 297, 306 (1976).

10. See, e.g., Fullilove v. Klutznick, 448 U.S. 448, 485-86 (1980) (upholding affirmative action "set-aside" program that did not reach all minority enterprises affected by discrimination); Cleland v. National College of Business, 435 U.S. 213, 220 (1978) (upholding limitation on veterans' educational benefits not placed on similar federal programs); Buckley v. Valeo, 424 U.S. 1, 105 (1976) (upholding federal campaign financing program that limited disbursement of matching funds to candidates who entered primaries); Joseph Seagram \& Sons, Inc. v. Hostetter, 384 U.S. 35, 51 (1966) (upholding New York statute limiting certain cut-rate sales of liquor).

11. 348 U.S. 483 (1955).

12. Id. at 489 . The sentence continues: "addressing itself to the phase of the problem which seems most acute to the legislative mind." This language is ambiguous: it is unclear whether the Court upheld the classification because the legislature adopted a piecemeal approach or because it struck where the harm was most acute. If influenced by the latter reason, the Court should not have resorted to the "one step at a time" justification. Instead, it should have declared that the parties were not similarly situated. See p. 1784 infra. If the Court approved the classification based on the legislature's piecemeal approach, then the case implies that a legislature should have great leeway in approaching such problems, provided that it perceives the step it takes to be a rational, if gradual, step toward its goal. Although the Court has not affirmatively resolved this issue, in subsequent cases involving underinclusive classifications it seems to have adopted the former justification. See p. 1780 infra.

13. 348 U.S. 483,489 (1955). 
meant that the legislature could neglect further steps permanently or only temporarily. ${ }^{14}$

Subsequent cases are equally unenlightening as to the meaning of "one step at a time." The Court has invoked the one step at a time justification to uphold classifications established after a legislature already had taken a series of steps, ${ }^{15}$ or already had begun a process of reform. ${ }^{16}$ In none of these cases, however, did the Court hold that further steps were constitutionally necessary. Rather, the Court has indicated often that although it might have been wiser for a legislature to go further, its failure to do so did not make the challenged classification unconstitutional. ${ }^{17}$ In other cases, involving legislative judgments that were not susceptible to a temporal analysis, the Court has quoted the one step at a time rationale without any indication of its actual relevance. ${ }^{18}$ These cases are not tied together by any clear doctrine explaining the one step at a time justification, but only by the rhetoric of judicial deference.

\section{Creating a Doctrine of Timebound Purposes}

In many cases decided on a one step at a time rationale, the challenged classification, though valid when litigated, will cease to be rationally related to its purpose within a foreseeable period of time. When that period

14. This ambiguity also appears in Minnesota v. Clover Leaf Creamery Co., $101 \mathrm{~S}$. Ct. 715 (1981), the most recent one step at a time case. In discussing the state's goal of encouraging environmentally acceptable containers, the Court stated that "[t]he Equal Protection Clause does not deny the State of Minnesota the authority to ban one type of milk container conceded to cause environmental problems, merely because another type, already established in the market, is permitted to continue in use," id. at 725, implying that a further step is not necessary. In discussing the goal of reducing economic dislocation, however, the Court suggested that the ban might be viewed in a different light if it were more than temporary: "The fact that the legislature in effect 'grandfathered' paperboard containers, at least temporarily, does not make the Act's ban on plastic nonreturnables arbitrary or irrational." Id. at 726.

More recently, a lower court has held that a one step at a time argument will fail without some indication that further steps are contemplated. See Delaware River Basin Comm'n v. Bucks County Water \& Sewer Auth., No. 80-1662, slip op. at 22 (3d Cir. Feb. 18, 1981).

15. See McDonald v. Board of Election, 394 U.S. 802, 811 (1969) ('[A]ppellants' challenge seems to disclose not an arbitrary scheme or plan but ... a consistent and laudable state policy of adding ... groups to the absentee coverage as their existence comes to the attention of the legislature.")

16. See, e.g., Califano v. Jobst, 434 U.S. 47, 57 (1977) (upholding amendment to Social Security Act although it was only "one firm step" towards eliminating hardship in previous rule); Buckley v. Valeo, 424 U.S. 1, 105 (1976) (upholding campaign financing law limiting matching funds to candidates who participate in party primaries); Katzenbach v. Morgan, 384 U.S. 641, 656-57 (1966) (prohibition of state literacy requirements permissible even though it only benefits persons instructed in schools within United States jurisdiction).

17. See, e.g., Califano v. Jobst, 434 U.S. 47, 57-58 (1977) ("Even if it might have been wiser to take a larger step, the step Congress did take was in the right direction ...."); McDonald v. Board of Election, 394 U.S. 802, 811 (1969) ("That Illinois has not gone still further, as perhaps it might, should not render void its remedial legislation .....")

18. See, e.g., Two Guys from Harrison-Allentown, Inc. v. McGinley, 366 U.S. 582, 592 (1961) (upholding Sunday law that imposed stiffer penalties on sale of commodities considered particularly disruptive to Sunday atmosphere); McGowan v. Maryland, 366 U.S. 420, 426 n.3 (1961) (upholding Sunday law that permitted sales of certain commodities). 
of time passes, and the classification is no longer valid, the law should be held unconstitutional under a means-end analysis. ${ }^{19} \mathrm{~A}$ timebound goal is not, of course, inherently legitimate, nor should the classification it creates be immunized even temporarily from further analysis. ${ }^{20}$ But if a timebound goal is legitimate, the constitutional status of the classification it supports should also be timebound under a means-end test.

\section{A. Types of Timebound Justifications}

There are two general types of timebound justifications. The first type stems from a legislature's often unstated but real need to deal with each issue that comes before it in as timely a fashion as possible, even if such consideration involves some sacrifice of thoroughness in the legislative scheme. ${ }^{21}$ This justification is common to all lawmaking; it arises from unavoidable limitations on legislative imagination and deliberative resources. ${ }^{22}$ Legislatures that considered every policy issue systematically and completely could not function rapidly enough in responding to social needs.

Although this limitation on the legislative process is inescapable, an equal protection justification invoking it is appropriate only when the legislature is unintentionally underinclusive ${ }^{23}$ and dissimilar treatment can-

19. This argument holds true even if equal protection analysis should consider only whether a legislative judgment was reasonable when it was made. See p. 1786 infra.

20. As defined here, timebound goals include only objectives premised on a set of circumstances that will by their nature cease to exist. Thus, not all goals premised on contingencies are timebound.

The Court has recognized timebound goals in areas of the law other than equal protection. See Jackson v. Indiana, 406 U.S. 715 (1972) (state may not institutionalize criminal defendant alleged to be incompetent to stand trial longer than reasonably necessary to determine whether substantial probability exists that defendant will become competent).

21. See Morse, Theories of Legislation, 14 DE PAUL L.REV. 51, 53 (1964). The need for timeliness can be characterized as an implicit legislative goal. Although that goal is inherent in every piece of legislation, it is almost never articulated. Thus, it would make no sense for courts to apply to it the rule that only purposes articulated in the legislative record may be used to justify a statute. $C f$ Califano v. Goldfarb, 430 U.S. 199, 212-13 (1977) (rejecting contention that Congress intended need to be criterion for Social Security survivors' benefits); Weinberger v. Wiesenfeld, 420 U.S. 636, 648 n.16 (1975) (rejecting contention that Congress intended gender-based classification to compensate women for economic discrimination).

22. See P. BREST, PROCESSES OF CONSTITUTIONAL DECISIONMAKING 565 (1975) (legislatures have limited time and resources). In fact, the legislative process has been likened in this regard to the judicial process. See Moffat, The Legislative Process, 24 CORNELL L. Q. 223, 229 (1930) (legislature is tribunal that considers "proposed changes in the rules governing our lives").

Moreover, representatives do not have time to give full consideration to each issue because of the large volume of legislation, the amount of time they must devote to constituents, and the degree of technical knowledge required to understand the background of every piece of legislation. CF. J. HARRIS, CONGRESS AND THE LEGISLATIVE PROCESS 162 (1972) ("Congress is not organized to formulate a broad, consistent, national legislative program dealing with the problems of the time."); Friendly, The Gap in Lawmaking - Judges Who Can't and Legislators Who Won't, 63 ColuM. L. REV. 787, 801 (1963) (because members of Congress spend at least half of their time on constituents, they can give full attention only to a limited number of issues); Schwarz, Legislation and Legislatures, 47 SOC. INQUIRY 234, 236 (1977) ("[L]egislators have little time to discuss and consider legislation . . ..")

23. Courts should examine the legislative record to determine whether limitations on the legisla- 
not otherwise be supported. In some of these cases the time constraints placed on legislative action do not sufficiently justify unequal treatment. ${ }^{24}$ In others the asserted interest is so trivial there is no need for further legislative consideration. ${ }^{25}$ There is an intermediate level, however, in which the interests asserted, while not demanding immediate vindication by the Court, are sufficiently important that the legislature should be required to consider them. For example, the legislative process justification could have been invoked in McDonald v. Board of Election Commission$e r s,{ }^{26}$ in which the Court rejected the claim that the Illinois legislature violated the equal protection clause by failing to include unsentenced prison inmates among classes of persons entitled to absentee ballots. The Court found no indication that the legislature had considered providing absentee ballots to pretrial detainees. In addition, the Court apparently believed that once the legislature recognized its inadvertent refusal to grant absentee ballots to unsentenced inmates, in accordance with its previous history, it would amend the law to include that group. ${ }^{27}$

The second type of timebound justification is based on the special characteristics of the problem being addressed by the legislature. Such characteristics include economic considerations and factual uncertainties. In

tive process were responsible for the exclusion being challenged. If extending the benefit in question to the plaintiff class was thoroughly considered and then rejected, the statute cannot be excused by imperfections in the legislative process. For example, in Maryland State Bd. of Barber Examiners v. Kuhn, 270 Md. 496, 312 A.2d 216 (1973), the court invalidated a statutory classification that implicitly restricted cosmetologists to cutting and shampooing women's hair. Because the same statute authorized cosmetologists to manicure the hands of both men and women, the state could not claim that the discriminatory restriction was inadvertent, and attributable only to limitations inherent in the legislative process. If, however, the legislature realized that it was passing an underinclusive statute but did not have time to study the merits of other provisions, the statute should only be upheld if the legislature has given some indication that it will enlarge the scope of its inquiry within a given period of time.

24. The courts have rejected the legislative process justification when applying heightened equal protection review. See Califano v. Westcott, 443 U.S. 76, 89 (1979) ("But Congress may not legislate 'one step at a time' when that step is drawn along the lines of gender . ....") In such cases, legislative inattention may serve as a cover for insensitivity or hostility. See J. ELY, supra note 5, at 157-60 (discussing use of stereotypes by legislature).

In addition, it may be wise to force the legislature to give especially thorough consideration to laws restricting important rights. See Craig v. Boren, 429 U.S. 190, 199 (1976) (legislature must identify instances where sex-based generalization actually comports with fact).

25. In such cases, courts should invoke simple deference rather than the one step at a time principle. See p. 1784 infra.

26. 394 U.S. 802 (1969).

27. Id. at 811. The Court also could have invoked a legislative process justification to uphold statutory classifications it upheld on the basis of purposes not articulated by the legislature. See, e.g., Cleland v. National College of Business, 435 U.S. 213, 220 (1978) (measure imposed was "direct response to problems experienced in the administration of this country's GI bills" and there was no evidence that Congress considered other federal grant programs); Buckley v. Valeo, 424 U.S. 1, 10506 (1976) (no indication that Congress determined whether candidates in primaries and candidates in petition drives were similarly situated). In each of these cases, the Court invoked the one step at a time justification without any further explanation of its significance. 
Minnesota v. Clover Leaf Creamery Co. ${ }^{28}$ the state legislature banned plastic but not paper nonreturnable milk containers, partially on the basis of economic considerations. The statute had two purposes. The first was to encourage the use of refillable containers and thus ease solid waste problems, reduce energy waste, and conserve natural resources. ${ }^{29}$ The second was to minimize the economic and social disruption that an immediate transition to refillable containers would cause. ${ }^{30}$ Although both purposes are legitimate, ${ }^{31}$ only the second is timebound: the dairy industry was put on notice that the legislature intended to promote refillable containers at the expense of nonrefillable containers. Accordingly, the dissimilar treatment of plastic and paper containers should not be continued after a suitable time for a switch to refillable containers passes.

The problem of factual uncertainty is illustrated by Aguayo v. Richardson. ${ }^{32}$ Plaintiffs challenged a statute requiring $25 \%$ of New York State welfare recipients to participate in one experimental work project, and $2.5 \%$ to participate in another project. ${ }^{33}$ In addition to its primary goal of improving the welfare system, the legislature sought to prevent waste of state resources on useless programs and to compare the results of different approaches. ${ }^{34}$ The nature of the experiment was such that the state would learn the value of the program only upon its termination. Therefore, the classification requiring only some of the state's welfare recipients to work in experimental projects should have been upheld only as long as the value of the program remained uncertain. ${ }^{35}$

\section{B. Proper Use of the One Step at a Time Justification}

The one step at a time justification can be a valid independent reason for a legislature to treat differently two groups that are similarly situated with respect to one objective only so long as the second goal that justifies the unequal treatment remains rationally related to the discriminatory

28. 101 S. Ct. 715 (1981).

29. Id. at 724-25.

30. Id. at 725-26.

31. The first goal addresses an area of legitimate local concern, environmental protection and resource conservation, and falls easily within the police power of the state. See Huron Portland Cement Co. v. Detroit, 362 U.S. 440, 442 (1960) (air pollution legislation clearly within police power). The legitimacy of the second goal is suggested by New Orleans v. Dukes, 427 U.S. 297, 305 (1976) (city could "rationally choose initially to eliminate vendors of more recent vintage" because they had not built up substantial reliance interests).

32. 473 F.2d 1090, 1109-11 (2d Cir. 1973).

33. Id. at 1094-96. The court upheld the classification, but did not explicitly employ a one step at a time justification.

34. Id. at 1109.

35. The court did not impose such a restriction, declaring that the equal protection clause was not violated if the selection of certain areas to test the program was rational, even if random. Id. at 1109 10. 
classification. By allowing a legislature to address problems in a piecemeal fashion, rather than requiring an all-or-nothing approach, courts encourage legislative creativity and accommodate political and economic reality. ${ }^{36}$ Accordingly, after a court has concluded the means-end inquiry, it should determine whether the purpose or justification used to uphold a classification is timebound. If it is not timebound, the court should declare that the parties are not similarly situated and uphold the classification. If it is timebound, the court should uphold the classification on a one step at a time rationale, but should also indicate that the requisite relationship between the means and the end will not continue indefinitely.

Courts should not invoke the phrase "one step at a time" as a purely rhetorical device when no other justification for a challenged statute seems convincing. The one step at a time paradigm should be reserved for timebound goals; otherwise its indiscriminate use will serve only to confuse legislatures and other courts. If a court desires to be deferential, it should find other means. ${ }^{37}$

\section{Encouraging Second Steps}

Statutes upheld solely on a one step at a time analysis should be reconsidered by the legislature or relitigated. This is unlikely, however, as long as the courts fail to understand the full implications of one step at a time analysis. ${ }^{38}$ To encourage second steps, courts should add a sunset provi$\operatorname{sion}^{39}$ to their orders, and hold classifications constitutional only for the specific period that corresponds to the nature of the legislature's timebound objective. If the legislature does not act within that period, the

36. See, e.g., Katzenbach v. Morgan, 384 U.S. 641, 657 (1966) (upholding Voting Rights Act, despite gaps, because measures to eliminate voting barriers should be encouraged); Aguayo v. Richardson, 473 F.2d 1090, 1109 (2d Cir. 1973) ("The Equal Protection clause should not be held to prevent a state from conducting an experiment designed for the good of all, including the participants, on less than a statewide basis."); cf. Tussman \& tenBroek, supra note 5, at 349 (courts must allow legislators to forge and test administrative solutions to complex problems).

37. For example, in Williamson v. Lee Optical, 348 U.S. 483 (1955), discussed at pp. 1779-80 supra, the distinction drawn between opticians and sellers of ready-to-wear glasses was not based on a timebound purpose. The Court should have required the state to show that the two groups were not similarly situated in order to justify treating them differently. The Court still could have shown substantial deference by applying to the legislature's factual finding only a minimal level of review. $C$. Vance v. Bradley, 440 U.S. 93, 111 (1979) ("[T]hose challenging the legislative judgment must convince the court that the legislative facts on which the classification is apparently based could not reasonably be conceived to be true by the governmental decisionmaker."); United States v. Carolene Prods. Co., 304 U.S. 144, 154 (1938) (legislative reading of facts controlling if question is "debatable").

38. Some one step at a time cases will be reviewed by the legislature or relitigated in the courts. Nevertheless, the scheme proposed here would facilitate the elimination of all timebound classifications once their justification ends and they become unconstitutional. See pp. 1786-88 infra.

39. The proposed provision would be analogous to a statutory sunset rule, which terminates the life of a program after a given number of years unless the legislature explicitly renews its mandate. See S. BREYER \& R. STEWART, ADMINISTRATIVE LAW AND REGULATORY POLICY 146-47 (1979). 
adjudication of constitutionality should lose its validity as a precedent and as a binding determination between the parties. If relitigated, the classification should be declared unconstitutional, unless some other justification for it can be found.

\section{A. The Power of Precedent}

A sunset order in the context of a classification upheld on the basis of a timebound justification is necessary because of the practical effect of judicial decisions. Cases are not confined to their facts when cited as precedent. Some holdings survive when no longer appropriate, forming the background for future judicial action. ${ }^{40}$ Under the doctrines of issue and claim preclusion, ${ }^{11}$ a party to the original litigation must bear the heavy burden of showing different or changed circumstances to relitigate successfully. ${ }^{42}$ In addition, courts generally have held that the passage of time is not in itself a material change in circumstances. ${ }^{43}$

The need for a sunset order is particularly evident in light of an important unresolved issue in equal protection doctrine. Some cases suggest that

40. See Linde, Due Process of Lawmaking, 55 NEB. L. REV. 197, 219 (1976) ("II]t is precedent and not specific facts that are adhered to."); $c f$. B. CARDOZO, THE NATURE OF THE JUDICIAL PROCESS 19-20 (1931) ("[S]tare decisis is at least the everyday working rule of law."); Holmes, The Path of the Law, 10 HARV. L. REV. 461, 492 (1897) ("Everywhere the basis of principle is tradition, to such an extent that we even are in danger of making the role of history more important than it is.")

41. The doctrine of issue preclusion holds that "[a] judgment in favor of either the plaintiff or the defendant is conclusive, in a subsequent action between them on the same or a different claim, with respect to any issue actually litigated and determined if its determination was essential to the judgment." RestatenenT (SECOND) OF JUDGMENTS § 45(c) (Tent. Draft No. 1, 1973).

Issue preclusion also prevents a party from contesting a previously litigated issue with a third party "unless the first party lacked full and fair opportunity to litigate the issue in the first action or unless other circumstances justify affording him opportunity to relitigate the issue." RESTATEMENT (SECOND) OF JUDGMENTS $\S 88$ (Tent. Draft No. 2, 1975).

Claim preclusion doctrine prevents the parties from reasserting the same cause of action once a judgment has been given. See RESTATEMENT (SECOND) OF JUDGMENTS §§ 45(a), (b) (Tent. Draft No. 1, 1973). The judgment need not have been on the merits, but the cause of action must be based on the same transaction. See Glick v. Ballentine Produce, Inc., 397 F.2d 590 (8th Cir. 1968). When claims are precluded, even issues not raised during the original litigation may not be litigated if based on the same claim.

42. See, e.g., In re Tennessee Cent. Ry., 498 F.2d 904, 906 (1974) ("[T]he principles of res judicata would govern the disposition of this case, even if there had been . . . a change in controlling case law."); Barzin v. Selective Serv. Local Bd. No. 14, 446 F.2d 1382, 1383 (1971) (res judicata holds "even if a contrary judicial decision on the legal issues involved intervenes between the first and second suits"); Bankers Mortgage Co. v. United States, 423 F.2d 73, 80 (1970) (res judicata holds where no substantial intervening change in controlling facts or applicable legal principles); RESTATE MENT (SECOND) OF JUDGMENTS $\S \S 61.2(f), 61.2(2)$ (Tent. Draft No. 1, 1973) \& $\$ 121$ (Tent. Draft No. 6, 1973) (change in circumstances must be substantial enough that giving continued effect to judgment is unjust).

43. See, e.g., United Bhd. of Carpenters v. Brown, 343 F.2d 872, 885 (10th Gir. 1965) (mere passage of time not sufficient to prove change of circumstances); Cory v. Commissioner, 159 F.2d 391 (3d Cir. 1946) (although each year's claim against taxpayer was separate, resolution of one year's claim was res judicata with respect to subsequent claims); Duquesne Slag Prods. Co. v. Lench, 415 A.2d 53 ( $\mathrm{Pa}$. 1980) (passage of 28 years not material change of circumstances). 
courts should only consider whether a legislative judgment was reasonable when it was made. ${ }^{44}$ Other cases suggest that courts should engage in an ongoing review that may reach different results as circumstances change. ${ }^{45}$ The analysis here is consistent with either position in this controversy. Legislation that fits the one step at a time paradigm is inherently timebound, even at the time of enactment, because one of its goals is inherently timebound. This does not mean that all legislation should undergo continuing review in light of possible unforeseen changes in circumstances. It merely means that some laws depend for their validity on circumstances that will change in a foreseeable period of time. A sunset order would make it clear that a court reviewing legislation a second time could invalidate a law that was rational when enacted only if the original timebound justification had lapsed. ${ }^{46}$

In the absence of a sunset order, a declaration of constitutionality discourages reconsideration not only by courts but also by the legislature. Once a court has given its imprimatur, the constitutionality of a classification, justified originally by the legislature for temporary reasons, is no longer conditioned on time. It is unlikely that a legislature will spend the time and energy needed to look past a holding that its goals are legitimate and sufficient to justify the classification. ${ }^{47}$ Moreover, many classifications, once enacted, create vested interests that exert pressure to retain the status quo, and such pressure only increases when a classification is upheld in the courts. ${ }^{48}$

44. Sec, e.g., Minnesota v. Clover Leaf Creamery Co., 101 S. Ct. 715, 724 (1981) ("WW]here there was evidence before the legislature reasonably supporting the classification, litigants may not procure invalidation of the legislation merely by tendering evidence in court that the legislature was mistaken."); Lindsley v. Natural Carbolic Gas. Co., 220 U.S. 61, 78 (1911) ("When the classification in such a law is called in question, if any state of facts reasonably can be conceived that would sustain it, the existence of that state of facts at the time the law was enacted must be assumed.") According to Hans Linde, it does not matter what the present facts are, but only that "legitimate ends and rational means . . coincide at the time of the legislative decision." Linde, supra note 40, at 217.

45. See United States v. Carolene Prods. Co., 304 U.S. 144, 153 (1938) ("[T]he constitutionality of a statute predicated upon the existence of a particular state of facts may be challenged by showing to the court that those facts have ceased to exist."); Milnot Co. v. Richardson, 350 F. Supp. 221 (S.D. Ill. 1972) (invalidating statute because no longer rational, although previously upheld in two Supreme Court cases).

46. Similarly, if a law based on a timebound purpose is first challenged after the purpose has lapsed, the reviewing court should strike it down, even if the court limits its inquiry to the rationality of the law when enacted, because the rationality is timebound.

47. Cf. J. HARRIS, supra note 22, at 19 (Congress unable to enact legislation until problem reaches crisis proportions); S. KRISLOV, THE SUPREME COURT IN THE POLITICAL PROCESS 144 (1965) (most Court decisions never come to attention of Congress).

48. See Linde, supra note 40 , at 221 ("Even a law originally enacted to serve one pragmatic end, such as health or safety, will remain on the books as long as other vested interests that have grown up around the law retain legislative sympathy.")

In Williamson v. Lee Optical, 348 U.S. 483 (1955), the Oklahoma legislature received notice in 1955 that its different treatment of opticians and ready-to-wear glasses retailers was justified only as a one step at a time reform. The legislature did not amend the statute, however, until 1978. 1978 Okla. Sess. Laws, ch. 37, §§ 2-6 (codified at OKLA. STAT. ANN. tit. 59, $\S \S 943.1-943.3$ (West Supp. 1980- 


\section{B. How A Sunset Provision Would Work}

Sunset orders in one step at a time cases should have two features. First, the court should explicitly state that it is upholding a law on the basis of a timebound justification and that it does not expect to be able to render the same decision some number of years hence. Such a statement will make it clear to the legislature, other courts, and other litigants that the statute's constitutionality is timebound. Second, the court should issue an order carefully delineating the issues that may be raised if the statute is relitigated, and thereby clarify the parties' rights to further causes of action.

A sample order would state: "Judgment for defendant, without prejudice to plaintiff's or any other party's right to bring an action to determine whether the classification is rationally related to its timebound purpose after $x$ years." 39 Such an order would confirm that the statute is constitutional as of the present. Claim and issue preclusion would bar the parties from contesting further the constitutionality of the statute for a given number of years. ${ }^{50}$ Stare decisis would restrict a different plaintiff's ability to raise the claim before the time period expired..$^{51}$ Subsequently, however, either the original plaintiff or a new one could argue that the timebound purpose had lapsed, without having to overcome the effects of res judicata. The defendant, on the other hand, would have to overcome the burden of proving changed circumstances ${ }^{52}$ in order to argue that the classification was rationally related to another purpose or that the purpose was not actually timebound..$^{53}$

1981)).

49. Courts have issued similar orders in other proceedings. In some cases, courts expressly reserve a plaintiff's right to maintain a second action, and in subsequent proceedings the plaintiff is not barred from reasserting the part of the claim that was reserved. See United States v. Seckinger, 397 U.S. 203, 206 (1970) (suit by United States against contractor not barred by res judicata when claim reserved by district court in prior action); Dudley v. King, 285 P.2d 425, 428 (Okla. 1955) (judgment for defendant reserved question of liability but barred question whether express contract was made); RESTATEMENT (SECOND) OF JUDGMENTS § 61.2(1)(b) (Tent. Draft No. 1, 1973).

When an action is premature or a precondition has not been satisfied, courts have held that the parties are not precluded from maintaining an action when the claim becomes enforceable. See, e.g., Williams v. Murdoch, 330 F.2d 745 (3d Cir. 1964) (petition in prior proceeding held defective for lack of verification); Bland v. Connally, 293 F.2d 852, 855 (D.C. Cir. 1961) (dismissal of prior complaint for failure to exhaust administrative remedies); RESTATEMENT (SECOND) OF JUDGMENTS $\S$ 48.1(2) (Tent. Draft No. 1, 1973).

50. See note 41 supra.

51. See Duncan v. Theis, 613 F.2d 305, 310-11 (Temp. Emer. Ct. App. 1979) (previous decision on claims identical to those in instant case should be followed on principle of stare decisis).

52. See p. 1785 supra.

53. These issues would be barred by the finding of the court in the first action. See Acree v. Air Line Pilots Ass'n, 390 F.2d 199 (5th Cir. 1968) (res judicata bars relitigation of issues determined by court and those that might have been presented). The proposed procedure imposes res judicata burdens on the defendant rather than on the plaintiff, although normally the plaintiff challenging the classification bears the burden. Thus the defendant would have an incentive to prove his claims in the initial proceeding rather than to rely on the one step at a time justification. The defendant would also 
The proposed sunset provision would encourage second steps and still permit the deference consonant with the level of review that the court applies. $^{54}$ The court's order would present the legislature with four choices. First, it could repeal the law. Second, it could amend the law to eliminate the challenged classification. Third, if the court had limited its analysis to purposes in the legislative record, the legislature could reenact the law containing the classification, grounding it this time on a previously unarticulated legitimate goal that is not timebound. Finally, the legislature could simply wait for relitigation to occur. A sunset order thus would allow a legislature to choose from among a number of alternatives, and at the same time, would encourage it to undo the imbalance created by an underinclusive statute. ${ }^{55}$

The most difficult aspect of fashioning a sunset provision would be to determine when the second step should begin. ${ }^{56}$ When the timebound jus-

be barred by res judicata from later challenging the court's decision to allow the plaintiff to seek a remedy in the second action. See Erickson v. United States, 309 F.2d 760, 765 (Ct. Cl. 1962) (erroneous determination that particular claim must be enforced in separate proceeding res judicata between parties).

54. The remedial scheme proposed in this Note permits courts to give a legislature time to consider an issue, and thus to avoid the problem of deciding whether to invalidate or broaden a timebound statute. If the issue is relitigated, however, and the court finds that the timebound goal has lapsed, it must consider in each case whether the statutory classification should be repealed or widened. Cf. Califano v. Jobst, 434 U.S. 47, 56 n.14 (1977) (problem "could be cured either by invalidating the entire exception or by enlarging it"); Note, Extension Versus Invalidation of Underinclusive Statutes: A Remedial Alternative, 12 COLUM. J.L. \& SOC. PROB. 115 (1975) (courts should consider remedy on case-by-case basis). But cf. Bickel \& Wellington, Legislative Purpose and the Judicial Process: The Lincoln Mills Case, 71 HARV. L. REV. 1, 14-35 (1957) (recommending that Court return bill to Congress when Congress has failed to provide appropriate remedy).

55. A sunset provision resembles a prospective overruling, which starts not at the date of decision but at some future time determined by the court. See Note, Prospective-Prospective Overruling, 51 MINN. L. REV. 79 (1966); cf. G. CALABRESI, COMMION LAW COURTS IN THE AGE OF STATUTES ch. 11 n.2 (forthcoming book on file with Yale Law Journal) (discussing different types of prospective overruling). This technique is designed to give a legislature time to reconsider an issue; it encourages legislative action. Although prospective overruling and sunset orders may have similar effects, they differ in several important respects. First, overruling creates a change in law, while many cases involving one step at a time justifications apply well-settled law. Second, the sunset provision is based on equal protection theory, while prospective overruling is based on prudential considerations such as the purpose of new standards, good-faith reliance on old law, or the effect on the administration of justice of retroactive application of new standards. Cf. Hankerson v. North Carolina, 432 U.S. 233, 242-43 (1977) (discussing criteria for prospective overruling). Finally, a sunset provision would not be subject to Article III limitations. Cf. Stovall v. Denno, 388 U.S. 293, 301 (1968) (Article III requires federal courts to extend benefits of prospective overruling to the parties in case sub judice). The plaintiff in a one step at a time case seeks to have the statute declared unconstitutional, and that issue is directly confronted by the court. The fact that the court's order contains a sunset element indicates that the plaintiff lost that issue, but is free to raise the same issue in a number of years.

56. This problem could be resolved if the litigants could agree on a date. Cf. Morales v. Turman, 383 F. Supp. 53, 126 (E.D. Tex. 1974), rev'd and remanded, 535 F.2d 864 (5th Cir. 1976), rev'd and remanded, 430 U.S. 322 (1977) (ordering parties to negotiate remedy after determination of violation); Patterson v. American Tobacco Co., 8 Empl. Prac. Dec. 6003, 6008 (E.D. Va. 1974), aff'd in part, modified in part and remanded, 535 F.2d 257 (4th Cir.), cert. denied, 429 U.S. 920 (1976) (same). Such an agreement would not, however, relieve the court of its duty to scrutinize carefully the chosen time period. 
tification is of the second type, one that arises from the nature of the problem being confronted, the legislature's announced objectives often may serve as a guide to an appropriate time period. ${ }^{57}$ For instance, the timebound objective of protecting existing economic interests should be tied to the economic life of the entity involved. If the state is undertaking an experiment, the time limit should be tied to a reasonable estimate of the experiment's duration. If the legislature has chosen an unreasonable termination date or has neglected to set one, the court should examine the record to determine a reasonable date. ${ }^{58}$

When the timebound justification is of the first type, one that arises from defects in the legislative process, the court would have less guidance in arriving at appropriate time limits. The court should base its decision on the relative importance of the interests at stake and on expert testimony as to the time it would take a legislature with limited resources and varied priorities to resolve the particular issue. ${ }^{59}$

\section{Two Examples}

The application of the proposed one step at a time model can be illustrated through a reexamination of two one step at a time cases. In Cleland v. National College of Business, ${ }^{60}$ the Court determined that the purpose of Congress was to avoid subsidizing "those [educational] institutions which could survive only by the heavy influx of Federal payments."61

57. The easy cases are those in which the second step is planned or will occur without further legislative action. E.g., New Orleans v. Dukes, 427 U.S. 297 (1976) (ban on all vendors would occur naturally as grandfathered vendors stopped operating). If the legislature does not set an explicit time limit but instead refers generally to reliance interests or settled expectations, the court would have to make an independent determination.

Nonconforming use doctrine in zoning law may help determine by analogy when reliance interests are extinguished. Under this doctrine several communities have placed a time limit on the nonconforming use exception to new regulations, allowing affected parties to recover the cost of their investments, but not to benefit from them in perpetuity. See, e.g., Harbison v. City of Buffalo, 4 N.Y.2d 553,152 N.E.2d 42, 176 N.Y.S.2d 598 (1958) (upholding constitutionality of amortization plan); $R$. POWELL \& P. ROHAN, POWELL ON REAL PROPERTY at $971-72$ (abr. ed. 1973) (discussing nonconforming use doctrine); Comment, The Abatement of Preexisting Nonconforming Uses Under Zoning Laws: Amortization, $57 \mathrm{NW}$. L. REV. 323 (1962) (arguing grace period should be long enough so that investment is completely amortized).

58. Courts commonly examine the record in selecting remedies to achieve desegregation. See, e.g., Evans v. Buchanan, 416 F. Supp. 328 (D. Del.), modified, 555 F.2d 373 (3d Cir.), cert. denied, 434 U.S. 880 (1977); Boston Chapter, NAACP, Inc. v. Beecher, 371 F. Supp. 507 (D. Mass.), affd, 504 F.2d 1017 (1st Cir. 1974), cert. denied, 421 U.S. 910 (1975); Martarella v. Kelly, 359 F. Supp. 478 (S.D.N.Y. 1973).

59. Cf. State v. Barquet, 262 So. $2 d 431$ (Fla. 1972) (effective date of ruling declaring Florida abortion law unconstitutional delayed to permit legislative revision); In re Jeruzal's Estate, 269 Minn. 183, 130 N.W.2d 473 (1966) (delaying effective date of decision overruling trust exemption until adjournment of next legislative session); Spanel v. Mounds View School Dist., 264 Minn. 279, 118 N.W.2d 795 (1962) (delaying effective date of decision overruling sovereign immunity until adjournment of next legislative session).

60. 435 U.S. 213 (1978).

61. Id. at 219 . 
Congress chose to meet this objective by imposing several restrictions on the institutions to which students could apply their veterans' education assistance benefits. ${ }^{62}$ The statute was a response to Congress' long experience with the administration of the program, rather than a result of a general study of the effectiveness of federal education grant programs. ${ }^{63}$

The Court should not have assumed without proof that the abuses of the veterans' program were in some meaningful way different from the abuses of other educational assistance programs, ${ }^{64}$ and should have upheld the statute only on a one step at a time justification. It should have explained that the classification was timebound because Congress has been put on notice that to pursue its purpose it eventually would have to treat all student aid recipients similarly. ${ }^{65}$ The Court should then have ruled that the plaintiff could reassert his claims at the end of one legislative session. If the case were relitigated, the defendant should be presumptively barred from claiming that the two programs were not similarly situated, but should still be able to argue that the one session deadline should be extended.

In Minnesota v. Clover Leaf Creamery Co., the Court considered a statute that both encouraged the use of refillable containers and at the same time protected the reliance interests of the paper nonrefillable container industry. ${ }^{66}$ Unless it was shown that the plastic and paper containers had different environmental effects, ${ }^{67}$ the Court should have upheld the statute on a one step at a time justification, but it also should have stated that the reliance interests were timebound. It should have indicated that after an appropriate period of time the plaintiff could challenge the classification again. ${ }^{68}$ This approach would have made clear to the legislature that it could only differentiate between paper and plastic temporarily, but would also have given the legislature time to deal with the classification as it saw fit.

62. Id. at $214-15$.

63. Id. at 219-20. It should be noted that the Court may have been less than sympathetic to the claims presented because the party in court was a college and not a veteran.

64. See note 27 supra.

65. See pp. 1781-82 supra.

66. 101 S. Ct. 715 (1981); see p. 1783 supra.

67. For purposes of this example, the discussion assumes that there was no relevant nontimebound difference between paper and plastic containers, as did the Minnesota trial court and the Minnesota Supreme Court. See Clover Leaf Creamery Co. v. Minnesota, 289 N.W.2d 79, 82 (Minn. 1979). This issue was in fact contested; the legislature based its classification in part on a perceived difference in the environmental effects of plastic and paper. See Minnesota v. Clover Leaf Creamery Co., 101 S. Ct. 715, 724-27 (1981) (deferring to legislative judgment).

68. Because the record was not fully developed on the issue of the time required by the dairy industry to shift to returnable bottles, the Court probably should have remanded the case to the Minnesota courts for further fact-finding. 
One Step at a Time

\section{Conclusion}

Courts have invoked the one step at a time justification indiscriminately, in large part because its meaning is unclear. If it is a mode of disguising judicial deference, its use is inappropriate. If, however, it involves a recognition of the realities of political and economic processes, its use is commendable. Sanctioning timebound justifications is not enough, though. The courts should also adopt the sunset provision outlined in this Note to facilitate litigants' and legislatures' questioning of classifications that cease to be justified. Such a result would further the guarantee of equal protection under the laws. 